\section{Manpower needs}

Sir,-We read with interest your editorial (January 3) entitled "Manpower needs are not so easily estimated". We feel that, although you made some telling points, the bluntness of your critical edge and the scathing tone caused some impontant aspects of manpower problems and the role of the Manpower Services Commission (MSC) to be lost. The baby, to our dismay, went out with the bathwater.

First of all, the nature of the MSC and its relationship to the Department of Employment are by now well known to those with a practical interest in the field and are easily obtained. Perhaps the oppontunity to publicise its role might have been taken by a note on the fly leaf of the report on the manpower implications of offshore oil and gas. It is a pity, then, that you got your facts wrong and referred to both the MSC and the Petroleum Industry Training Board as agencies of the Department of Employment. And in drawing attention to a misprint you tempted providence in the form of the printer's devil, who inserted another in the same line of your own piece.

So, please let all of us eliminate, as you say, the "emotive turn of phrase" and give some careful thought to the critical problems of manpower-of which the manpower to enable us to exploit offshore oil and gas is not the least.

Perhaps the wisest statement of your editorial was the title: manpower needs are not so easily estimated. The UK has devoted ludicrously small resources to studying and forming policy about manpower. It is, after all, perhaps our most critical national resource (and that statement is fast becoming a cliché) and yet, as you rightly point out, we have not had the major, in depth, study that is really necessary to provide a sound basis for action at all levels in respect of skills and manpower needed to exploit the North Sea.

In such a situation, the arrival of the MSC as an independent voice is an important step forward. Its role and composition was established by the Employment and Training Act 1973. The MSC is financed through the Secretary of State for Employment (but is not part of the Department) and through the Training Services Agency co-ordinates the operation of the Industrial Training Boards.

At this early stage, it is surely appropriate for the MSC to promote and publicise pieces of work, particularly those that summarise what is known. In the process, some ideas will come forward to be dismissed and some good work will be overlooked. All this will draw attention to the paucity of current knowledge.
The report that you criticise, to quote the introduction, attempts to provide an overview by drawing together the threads of previous studies. There is no guarantee that a literature search will provide the answers to any problem. In the circumstances, and in view of the public debate that is taking place, the MSC is surely right to publicise the findings, but not to endorse necessarily the conclusions reached. In that way we will all learn.

Perhaps we could also take the opportunity to make some comment on the problems of the supply of qualified manpower, drawing on some of our own research. By and large, the employing organisations which create demand for people, on the one hand, and the education and training institutions which create a supply, on the other, operate pretty well independently of each other. Any impression that we can forecast the demand for (for example) geologists and then set up the courses to provide them is so oversimplified as to be useless. Accurate forecasts are not possible in any case. We have to know more about the absorption of graduates into the economy-some emigrate, others go back into education, others move rapidly away from straight application of their basic discipline. More needs to be learned about how university courses might develop in the interests of the individual and society (taking a very long term view). Even if we knew precisely what we wanted, there remains the question of how the educational system and the people in it react or might be helped to react. Industry is notoriously weak at anticulating a considered view (though you are right to say that many companies prefer to undertake specialist training of geologists themselves).

Thus, in regard to many aspects of manpower, we have an extraordinarily complex system working within a changing and unpredictable environment in which the components have very strong needs of their own.

Manpower needs are indeed not so easy to estimate. We trust we may see more encouragement of and support for those who are only now beginning to grapple with the problem.

Yours faithfully, JoHN LAWrence Graham Atrinson

Institute of Manpower Studies,

London School of Economics

\section{International meetings}

SIR,--The letter from S. Peller (December 13) is similar to so many of the past few years and raises again the recurring, vexing problem of the location of international conferences. Clearly assurances by some governments of entry to all participants are meant by these governments to be honoured in the breach. Starting from the premises that international scientific meetings should, in fact, be open to all qualified scientists, and that the internal affairs of the host country should not be interfered with, I should like to make the following suggestion.

Each international union should set up a committee to investigate complaints from bona fide scientists who have been barred from a meeting. If the charges are verified, then the union would bar that country as host for other meetings for a period of five years, the restriction to apply even to meetings already scheduled. Thus any country would have the choice of playing politics or hosting international meetings, but not both. Of course, some measures would also have to be taken to prevent the scientific union itself from becoming political, as has happened to UNESCO.

Variants of this method could also be considered. Thus a country which does not allow its scientists free access to meetings, such as, for example, the Soviet Union, could be barred from having any of its scientists attend such meetings.

\section{Yours faithfully, SAM Silverman \\ Lexington, Massachusetts 02173}

\section{Alien message}

SiR,--If an alien civilisation should chance to receive the radio message broadcast to the stars from the Arecibo telescope (January 24) it would be fully justified in reversing the charge for any reply. I make this assertion because, to judge from your illustration, the original communication was itself reversed, vertically. Which is to say, sir, it was upside down (not that the concept of tops and bottoms means very much in terms of inter-galactic messages).

As the message stands, an alien listener might just about make out that we are trying to tell him something about a man who appears to be balancing on his head at the top of a Maypole.

I for one shall be surprised if anybody (from this galaxy or the next) troubles to reply to such blather, unless it is to tell us that his chaps go in for Morris dancing while walking on their hands.

$$
\text { Yours faithfully, }
$$

Hove, UK

ED-Sorry; the message was garbled during transmission from the Nature office to the printing works. So much for the march of progress. 